\title{
Poorly Differentiated and Undifferentiated Thyroid Carcinomas
}

\author{
Catarina ELOY ${ }^{1,2}$, Luciana FERREIRA ${ }^{1,2}$, Catarina SALGADO ${ }^{1,3}$, Paula SOARES ${ }^{1,2,3}$, \\ Manuel SOBRINHO-SIMÕES $1,2,3,4$ \\ IInstitute of Molecular Pathology and Immunology of the University of Porto, Cancer Biology, PORTO, PORTUGAL \\ ${ }^{2}$ Medical Faculty of Porto University, Pathology and Oncology, PORTO, PORTUGAL \\ ${ }^{3}$ Instituto de Investigação e Inovação em Saúde, Universidade do Porto, PORTO, PORTUGAL \\ ${ }^{4}$ Hospital Centre of S. João, Pathology, PORTO, PORTUGAL
}

\begin{abstract}
Thyroid cancer is the most common endocrine malignancy and its incidence goes on increasing worldwide. The majority of thyroid tumours comprise well-differentiated (papillary and follicular) thyroid carcinomas that usually carry an excellent prognosis, while a minority progress to poorly differentiated carcinoma (PDTC) and, ultimately, to the highly aggressive and lethal undifferentiated carcinoma (UTC). Recently, some major advances have been made on the histologic and imunohistochemical identification, as well as on the molecular characterization of PDTC and UTC. In this review we summarize the most recent immunohistochemical and molecular findings in PDTC and UTC, giving a particular emphasis to the diagnostic and prognostic meaning of the genetic alterations.
\end{abstract}

Key Words: Anaplastic thyroid carcinoma, Non-medullary thyroid carcinoma, Molecular medicine, Small cell carcinomas, Poorly differentiated thyroid carcinoma

\section{INTRODUCTION}

The most important difference between the classifications of thyroid tumours in the WHO books of 1988 and 2004 concerns the individualization in the latter of the group of poorly differentiated carcinomas (PDTC) $(1,2)$. It was also recognized that all sorts of benign and malignant thyroid tumours may be composed by the individualization of oncocytic (oxyphilic or Hürthle) cells, thus leading to oncocytic/Hürthle cell variants of adenoma and of follicular papillary and poorly differentiated thyroid carcinoma (1). It is usually advanced that the absence of an oncocytic/ Hürthle cell variant of undifferentiated carcinoma (UTC) reflects the high mitotic ratio of such tumours (the cells of undifferentiated/anaplastic carcinoma divide too fast to allow the accumulation of mitochondria in their cytoplasm) (3).

The immunohistochemical and molecular characteristics of poorly differentiated and undifferentiated carcinomas were thoroughly addressed in the 2004 edition of the WHO book, as well as in a number of review papers by Garcia-Rostan et al., Nikiforov et al. (4-6) and Soares et al. (7) (Tables 1, 2).

Most of the problems found in the stratification of such immunohistochemical and/or molecular markers reflect differential diagnostic difficulties - it is not easy, for instance, to separate a poorly differentiated carcinoma from

(Turk Patoloji Derg 2015, 31(Suppl):48-59)

Received : 29.05.2015 Accepted : 03.06.2015 a widely invasive follicular carcinoma with a trabecular/ solid growth pattern - and the intrinsic heterogeneity of both groups of carcinoma.

Another problem regards the existence of several clinicopathological entities in thyroid oncology that may be considered as a sort of poorly differentiated carcinoma [e.g. (sclerosing) mucoepidermoid carcinoma and mucinous carcinoma)]. Such entities have been recently described and discussed in the 2014 - AFIP book on Thyroid and Parathyroid Tumours (8) and will not be addressed in the present review. The only exception concerns the group of Small cell carcinomas/Carcinoma of the thyroid with Ewing Family Tumour Elements (CEFTE) because it represents a particularly interesting end result of new developments in the immunohistochemical and molecular study of peculiar thyroid tumour that raise difficult differential diagnostic problems (9-12).

\section{POORLY DIFFERENTIATED CARCINOMA}

The histological description should follow the $2004 \mathrm{WHO}$ book and the AFIP book of Rosai et al. $(1,8)$ (Figure 1AE). The diagnostic guidelines and the histological pictures in the latter are excellent and review thoroughly the steps used in the diagnosis of PDTC following the algorithmic approach advanced by Volante et al. (13).

Correspondence: Manuel SOBRINHO-SIMÕES

IPATIMUP, Rua Roberto Frias s/n 4200-465

PORTO, PORTUGAL

E-mail: ssimoes@ipatimup.pt Phone: +351 225570700 
Table I: Poorly differentiated carcinoma

\begin{tabular}{|c|c|c|c|}
\hline \multirow[b]{2}{*}{ 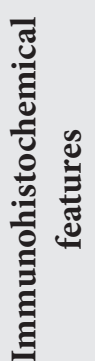 } & Antibodies usually expressed & Antibodies variably expressed & Antibodies usually not expressed \\
\hline & $\begin{array}{l}\text { Cytokeratins } \\
\text { TTF1 } \\
\text { Thyroglobulin (focal) } \\
\text { Ki-67 (labelling index is higher than } \\
\text { in well differentiated carcinomas) } \\
\text { Cyclin D1 }\end{array}$ & $\begin{array}{c}\text { Synaptophysin } \\
\text { p53 } \\
\text { E-cadherin }\end{array}$ & $\begin{array}{c}\text { Calcitonin } \\
\text { Chromogranin }\end{array}$ \\
\hline \multirow{10}{*}{ 总 } & Molecular alterations & Prevalence (\%) & References \\
\hline & RAS & $20-50$ & $(7) ;(4)$ \\
\hline & \begin{tabular}{|l|} 
TP53 \\
\end{tabular} & $15-40$ & $(7) ;(4)$ \\
\hline & $B R A F$ & $5-20$ & $(7) ;(4) ;(31)$ \\
\hline & CTNNB1 & $5-25$ & $(31) ;(28)$ \\
\hline & PIK3CA & $5-14$ & $(7) ;(4) ;(31)$ \\
\hline & PTEN & 20 & $(31)$ \\
\hline & AKT1 & $5-10$ & $(4)$ \\
\hline & TERT & $20-50$ & $(7) ;(36)$ \\
\hline & STRN/ALK & 9 & $(42)$ \\
\hline
\end{tabular}

PDTC: Immunohistochemical and molecular features (poorly differentiated carcinomas).

Table II: Undifferentiated thyroid carcinoma

\begin{tabular}{|c|c|c|c|}
\hline \multirow[b]{2}{*}{ 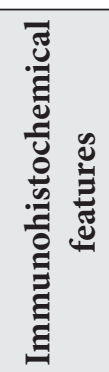 } & Antibodies usually expressed & Antibodies variably expressed & Antibodies usually not expressed \\
\hline & $\begin{array}{l}\text { Cytokeratins (usually focal) } \\
\text { Ki-67 (labelling index is higher than } \\
\text { in PDTC) } \\
\text { p53 } \\
\text { Vimentin } \\
\text { Cyclin D1 }\end{array}$ & $\begin{array}{l}\text { TTF1 } \\
\text { PAX8 } \\
\text { E-cadherin } \\
\text { EMA } \\
\text { P63 } \\
\text { CEA }\end{array}$ & $\begin{array}{c}\text { Calcitonin } \\
\text { Chromogranin } \\
\text { Thyroglobulin } \\
\text { Synaptophysin } \\
\text { Bcl-2 } \\
\text { CD31 } \\
\text { CD34 }\end{array}$ \\
\hline \multirow{10}{*}{ 离 } & Molecular alterations & Prevalence (\%) & References \\
\hline & TP53 & $50-80$ & $(19) ;(4)$ \\
\hline & TERT promoter mutation & $30-50$ & $(19) ;(56)$ \\
\hline & RAS & $4-60$ & $(49)$ \\
\hline & BRAF & $10-50$ & $(19) ;(4)$ \\
\hline & CTNNB1 & $5-66$ & $(29)$ \\
\hline & PI3KCA & $5-25$ & $(19)$ \\
\hline & PTEN & $5-15$ & $(19) ;(4)$ \\
\hline & $A K T 1$ & $5-10$ & (19); (4) \\
\hline & $A L K$ & $0-10$ & $(19)$ \\
\hline
\end{tabular}

UTC: Immunohistochemical and molecular features (undifferentiated carcinoma).

The most difficult diagnostic problems occur in the border between well differentiated (WDTC) and poorly differentiated carcinoma. The separation between papillary thyroid carcinoma (PTC) and PDTC is based upon the nuclear features of the neoplastic cells. In case the nuclei are of the PTC type the tumour is classified as a solid or trabecular variant of PTC regardless of the existence of necrotic foci and/or high mitotic number $(6,14,15)$. 


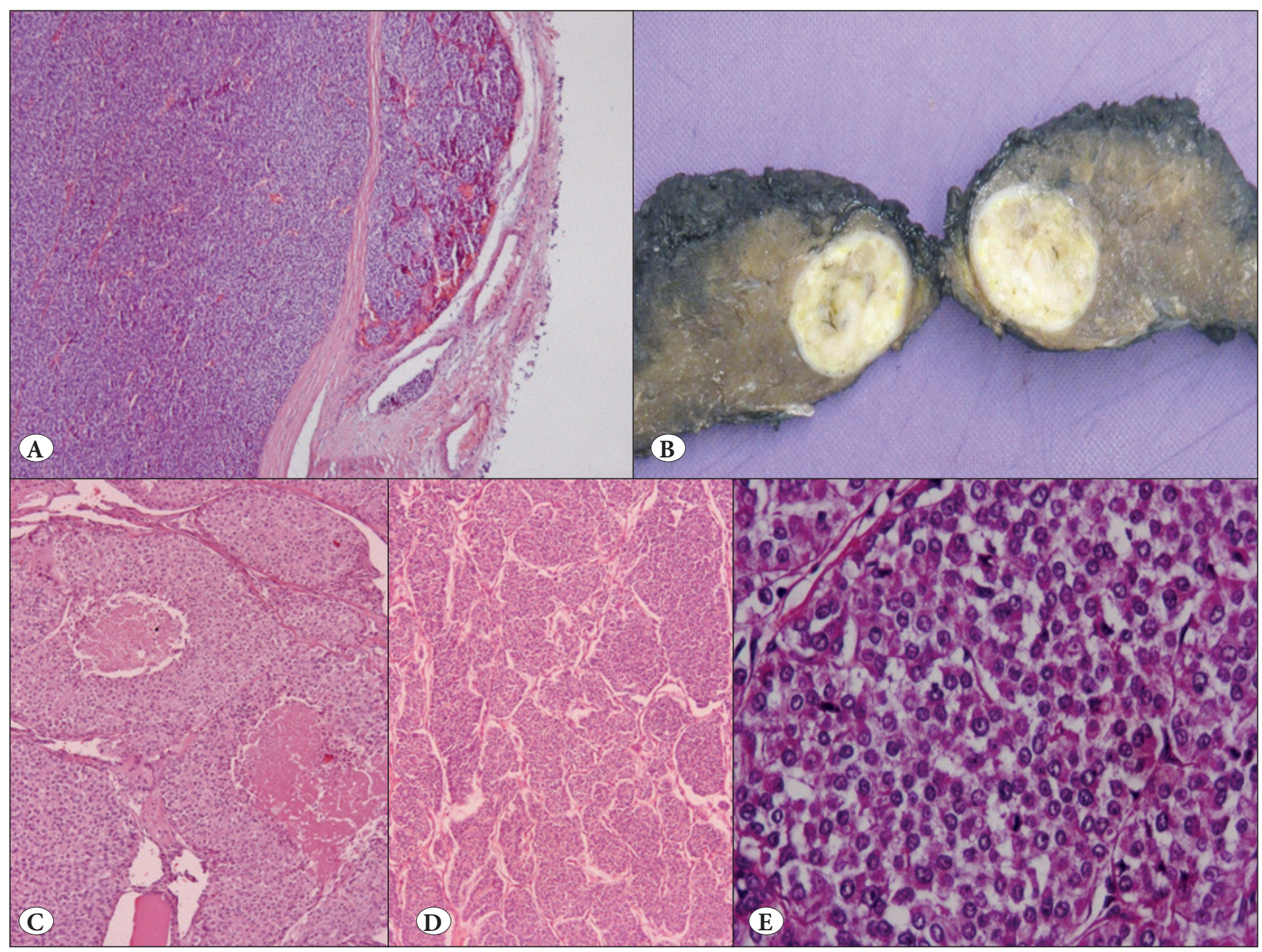

Figure 1: Poorly Differentiated Thyroid Carcinoma (PDTC): A) Tumour with expansive growth pattern, invasion of the capsule and images of vascular invasion, B) Macroscopic appearance of an apparently well circumscribed PDTC whose histological characteristics are documented below, C, D) Nested pattern area with foci of necrosis (H\&E, 40x), E) Focus with numerous mitoses and without PTC type nuclei (H\&E, 400x).

The separation between widely invasive follicular thyroid carcinomas (FTC) with foci of necrosis and/or high mitotic index and PDTC is almost impossible to establish in many situations (15). Molecular data did not provide so far any diagnostic clue and the pathology reports are written assuming the aforementioned limitations. This does not constitute a major drawback since the prognosis and treatments are similar in both situations $(1,8,15)$.

In different fields of well differentiated thyroid carcinomas there are reports of tumours displaying poorly differentiated features [e.g. cribriform morular variant of PTC (16)]. These cases should not be lumped together with common PDTC.

The differential diagnosis between PDTC and UTC/ anaplastic carcinoma may be difficult in intermediate cases but is based upon a very precise immunohistochemical feature: PDTC exhibits diffuse nuclear positivity for TTF1 and focal positivity, frequently with a dot-like pattern, for thyroglobulin, and UTC by definition are thyroglobulin negative and almost always TTF1 negative.

The hottest topic in the world of PDTC regards the diagnosis of PDTC, which do not exhibit unequivocal signs of capsular and/or vascular invasion. The question is simple but the answer is difficult. Which are the criteria for diagnosing a PDTC in an apparently non-invasive thyroid tumour? There are anecdotic reports in the literature claiming that such cases exist and have given rise to metastases (17). Ghossein et al. (18) did not find evidence supporting this claim and we must confess we do not know how to solve the problem. In real life, and whenever the 
tumour displays (very) aggressive histological features without showing concomitant signs of invasion, we sample the capsule completely and look at deeper sections of the tumour in an attempt to find such signs. The only molecular feature which might be used for making a diagnosis of noninvasive PDTC would be the demonstration of clonal TP53 mutations or diffuse nuclear immunoreactivity for p53, but even then the classification of noninvasive PDTC is questionable (we must confess we have never made such diagnosis).

In the future, there will hopefully exist drugs that can be efficiently used to treat patients with thyroid carcinomas not responding to radioactive iodine, in these settings the focus will rest on the identification of specific molecular targets rather than on the histological classification of the carcinomas.

The molecular features of PDTC are summarized in Table 1. Activating point mutations of the RAS gene typically affect codons 12,13 and 61 . At variance with differentiated thyroid cancer where NRAS codon 61 mutations are the most frequent, HRAS and KRAS codon 12 and 13 are also found mutated in PDTC $(4,7,19)$. Volante et al. reported $R A S$ mutations as the most common genetic alteration in PDTC (20). Moreover, the detection of RAS mutations appears to be clinically relevant in terms of prognosis, identifying a subset of more aggressive tumours (20). It was shown that PDTC cases with mutated NRAS are significantly associated with the appearance of haematogenous (particularly bone) metastases (19). Due to the association found between RAS mutations and guarded prognosis in PDTC and UTC, Wang et al. proposed that a particular attention should also be paid to WDTC, namely FTC, harbouring RAS mutations $(7,21)$.

TP53 gene, encoding a nuclear transcription factor that is typically involved in the negative regulation of the cell cycle and in promoting apoptosis, is a frequently impaired gene during thyroid tumour dedifferentiation (22-24). In thyroid, TP53 shows a mutational pattern located in known hotspots (exons 5-9) in 15-40\% of cases. Moreover, there is a relatively good correlation between mutations and p53 immunohistochemical reactivity: aberrant p53 immunoreactivity is detectable in $40-50 \%$ of $\operatorname{PDTC}(1,7,19)$. TP53 mutation seems to be (one of) the dedifferentiation switches necessary for progression and dedifferentiation in thyroid tumours (7).

$B R A F^{V 600 E}$ mutation occurs in $5-20 \%$ of $\operatorname{PDTC}(25,26)$. Many of these carcinomas also reveal areas of PTC, and $B R A F^{V 600 E}$ is present in both tumour components, thus suggesting that this mutation is an early event that do not impair tumour dedifferentiation (4). In accordance with a stepwise progression model, BRAF mutations are almost exclusively found in PDTC arising from PTC, being extremely rare in PDTC associated with FTC (7). RicarteFilho et al. (27) reported that 39\% of PDTC, FDG-PET positive tumours refractory to radioactive iodine (RAI) treatment harbouring $B R A F$ mutations, whereas non-RAIrefractory PDTCs display a significantly lower prevalence of BRAF mutations (12\%) (27). These results indicate that $B R A F$ mutated PDTC are more often refractory to RAI treatment than $B R A F$ wild type PDTC.

Two of the most common rearrangements in WDTC are RET/PTC and PAX8/PPARy (4); however, these specific rearrangements are only rarely detected in PDTC (19). This finding suggests that WDTC harbouring such rearrangements do not usually evolve toward less differentiated carcinomas, thus reinforcing the assumption that the majority of "rearranged" PTC and FTC cases do not tend to progress towards further advanced steps of neoplastic development (19).

Another gene reported as frequently mutated in PDTC and UTC is CTNNB1, which encodes $\beta$ catenin that is involved in cell adhesion and WNT signalling (4). The seminal paper of Garcia-Rostan et al. (28) showed a frequency of $25 \%$ of CTNNB1 mutations in PDTC. The activating mutations cluster in exon 3 at the phosphorylation sites for ubiquitination and degradation of $\beta$-catenin and are associated with aberrant nuclear immunoreactivity, suggesting WNT pathway activation $(28,29)$. In contrast Rocha et al. (30) did not find mutations in CTNNB1 nor in the $C D H 1$ gene (encoding E-cadherin) in a series of PDTC. Rocha et al. observed alterations of protein expression, concluding that loss of E-cadherin rather than CTNNB1 mutation appears to be the crucial event in determining the degree of differentiation of thyroid carcinomas $(19,30)$. In accordance with these latter results, Pita et al. (31) found CTNNB1 mutations in a minority (5\%) of PDTCs.

Thyroid carcinoma dedifferentiation involves also the progressive accumulation of other mutations, particularly those in genes that encode effectors of the PI3K-AKT pathway, such as the PIK3CA (the gene that encodes PI3K), AKT1 and PTEN (4). Among PDTC carcinomas, 5-14\% harbour mutations in PIK3CA, 20\% in PTEN and 5-10\% in AKT1 $(4,8,31,32)$.

Telomerase activation is known to be a hallmark of cancer being detected in up to $80 \%$ of malignant tumours (7). Normal thyroid tissue is thought to be telomerase 
negative, thus raising the possibility that the reactivation of telomerase may be a useful marker of tumour development $(33,34)$. TERT promoter mutations were found in $20-50 \%$ of PDTC $(8,33,35,36)$. These findings concur with the evidences that TERT promoter mutations associates with a more aggressive behaviour of thyroid tumours $(37,38)$.

Some PDTC and every UTC constitute the majority of clinically aggressive tumours that cause the death of the patients. In an attempt to address this lethality, efforts have been made for identify other genetic alterations in less differentiated and undifferentiated thyroid carcinomas that could pinpoint new therapeutic targets. Analysis of miRNA expression in normal thyroid tissue and in major types of thyroid tumours revealed that the majority of known miRNAs were expressed in normal thyroid tissues, whereas in thyroid neoplasms $32 \%$ of miRNAs were found to be consistently upregulated, and $38 \%$ were downregulated with more than a 2 -fold change as compared to normal tissue (39). The most highly upregulated miRNAs in PDTC were miR-187, -221, -129, -222, -146b, -339, -183 (39).

The rearrangement involving the anaplastic lymphoma kinase (ALK) gene (40) and the striatin (STRN) gene (STRN/ ALK) leads to constitutive activation of ALK kinase via dimerization mediated by the coiled-coil domain of STRN and to a kinase-dependent, thyroid-stimulating hormoneindependent proliferation of thyroid cells. Expression of STRN/ALK transforms cells in vitro and induces tumour formation in nude mice. Kelly et al. (41) reported this gene arrangement in 9\% of PDTC and demonstrated that STRN/ALK gene fusion occurs in a subset of patients with aggressive types of thyroid cancer, providing initial evidence that ALK inhibitors may represent a therapeutic option in these cases (41).

Other molecular alterations include downregulation of genes responsible for specialized thyroid function and in cell adhesion, upregulation of genes involved in motility and cell-cell interaction, and different patterns of deregulation of the expression of genes that encode cytokines and other proteins involved in inflammation and immune response. Although the list of specific deregulated genes varies substantially between different studies, a number of genes have been consistently found to be deregulated at the mRNA level: MET, TPO, TIMP1, DPP4, LGALS3 and KRT19 (42-46).

\section{UNDIFFERENTIATED (ANAPLASTIC) CARCINOMA}

For a thorough and extremely competent review on the macroscopic and histologic aspects of these tumours please see the respective AFIP chapter (8). A typical case of UTC is illustrated in Figure 2A,B. The immunohistochemical and molecular data on the whole group are summarized in Table 2.

Undifferentiated thyroid carcinoma (UTC) corresponds to the most aggressive form of thyroid cancer, being the final step of the progression of thyroid epithelial neoplasms. The concept of stepwise progression from a pre-existing welldifferentiated thyroid carcinoma to poorly differentiated and undifferentiated carcinoma is supported by clinical, epidemiologic, pathologic and molecular evidence (studies of loss of heterozygosity, comparative genomic hybridization, genetic and epigenetic alterations), although anaplastic carcinoma may apparently also arise de novo (7, 47, 48).

Thyroid tumours are part of the minority of those human cancer types that do not follow the classical Vogelstein model, in which mutational inactivation of TP53 is a crucial step in the first steps of progression (from adenoma
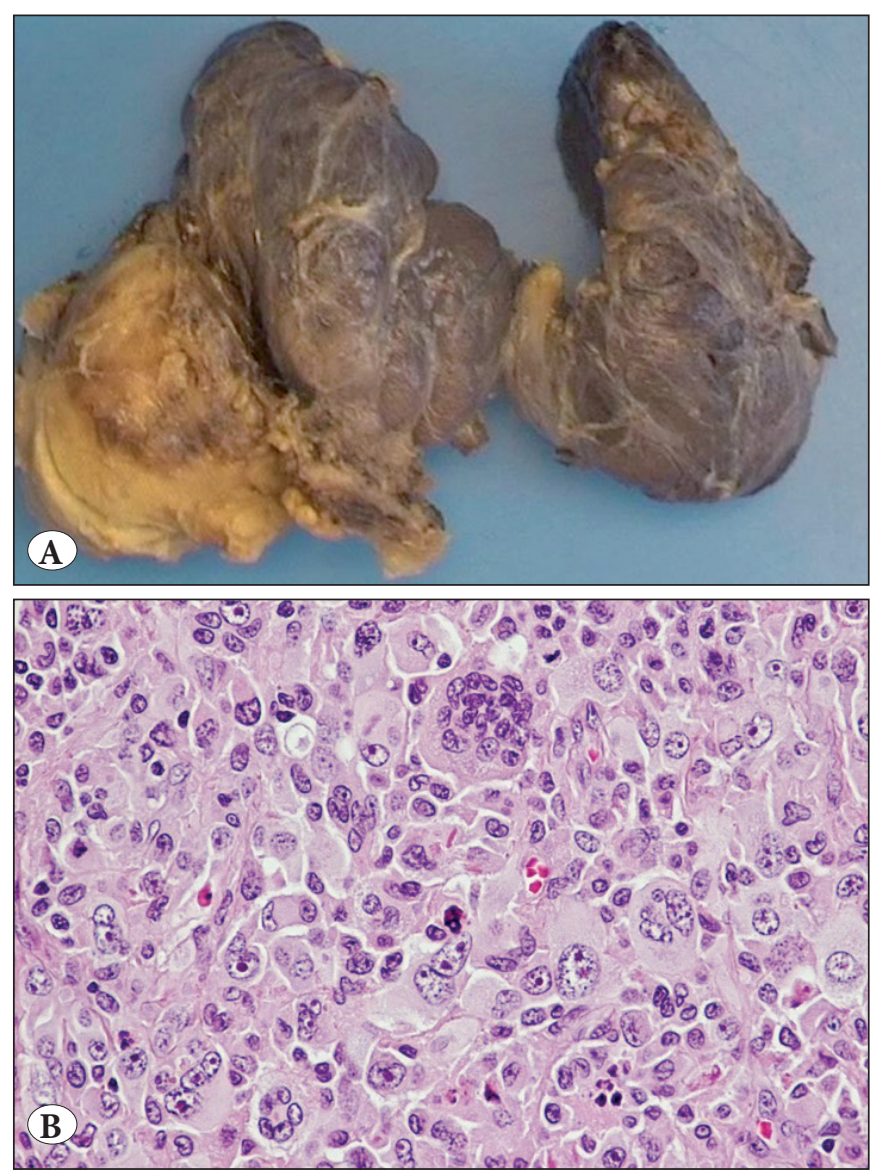

Figure 2: Undifferentiated Thyroid Carcinoma: A) Large tumour that grows beyond the thyroid limits, B) The neoplastic cells are mitotically active, atypical and pleomorphic displaying epithelioid to spindle cell morphology and co-existing with giant cells (H\&E, 400x). 
to carcinoma) (49). TP53 gene inactivation seems to play a major role in the progression from differentiated to undifferentiated carcinoma, being a late event in the carcinogenic process and occurring together with a marked increase of cell proliferation (7). At variance with welldifferentiated tumours in which TP53 gene mutations are rare, in UTC the loss of function mutations in different reports ranges from 50 to $80 \%(19,27,50-52)$. Many studies have shown that, when the same tumour contained welldifferentiated and undifferentiated components, TP53 mutation was restricted to the anaplastic foci $(50,53,54)$. No clear prognostic significance has been attributed to the presence of TP53 mutations in UTC.

The second most frequent genetic alteration in UTC is the recently described TERT promoter mutation. The -124 and -146 mutations in TERT promoter are detected in up to $50 \%$ of UTC; this percentage is higher to the percentage found in PDTC, and much higher than that reported in well-differentiated thyroid carcinomas $(8,55)$. The -124 mutation occurs more frequently, being the two mutations mutually exclusive. It was reported that -124 and -146 TERT promoter mutations coexist frequently with $B R A F^{V 600 E}$ mutation $(33,35,36)$. In one report, Landa et al. (37) stated that TERT promoter mutations were collectively associated with BRAF and RAS mutations when UTC and PDTC were lumped together. Recently, Shi et al. (56) found that a-124 TERT promoter mutation in UTC is typically associated with older age of the patients and with distant metastasis, thus suggesting that this mutation plays an important role in the pathogenesis and aggressiveness of UTC.

The prevalence of RAS mutations in UTC ranges from 4 to $60 \%(13,31,57,58)$. Activating point mutations typically affect codons 12, 13 and 61 of the NRAS gene. In vitro RAS activation leads to the rapid loss of differentiation markers, such as thyroglobulin, thyroid peroxidase, and thyrotropin receptor, and increased proliferation, but it is not sufficient to induce per se complete transformation of thyroid cells (59-61). Dedifferentiation is likely not driven by RAS mutations individually, but rather by the combined effect of multiple genetic alterations (62) including TP53 and TERT promoter gene mutations

The BRAF ${ }^{V 600 E}$ point mutation that constitutes about 9899\% of all BRAF mutations found in thyroid cancer, and it is present in up to $40 \%$ of UTC $(25,27,63)$. Nikiforov et al. (47) reported that BRAF mutation was detected in areas of PTC and of PDTC or UTC coexisting in the same tumours, providing molecular evidence for stepwise progression from PTC to PDTC and UTC. The results on the record also suggest that constitutive activation of $B R A F$ may predispose to such a progression, although it appears that this mutation represents an early event and additional genetic alterations (namely TP53 mutation) are required to promote the process of dedifferentiation (47).

Molecular alterations are progressively accumulated in thyroid cancer during the dedifferentiation process, and this occurs particularly in those genes that encode effectors of the PI3K-AKT pathway. Among UTC, $5-25 \%$ of the tumours harbour mutations in PIK3CA (8), 5-15\% PTEN mutations and 5-10\% AKT1 mutations (22, 27, 32, 64). Amplification of the PIK3CA genomic locus in 3q26.3 is found in about $40 \%$ of UTC suggesting that alteration of the PI3K-AKT pathway plays a pivotal role in the pathogenesis of UTC (55).

The STRN/ALK gene rearrangement has been identified in a subset of UTC that appears to develop from PTC. This gene rearrangement was also reported in one of 24 UTC coexisting with a follicular variant of PTC component (41). Murugan et al. (65) identified activating point mutations in $A L K$ (encoding the tyrosine kinase domain of the protein) in two tumours from a series containing 18 UTC.

Recently, a critical role for miRNAs in carcinomas has emerged with increasing evidence showing that they may drive and potentiate tumourigenesis and neoplastic progression. Some miRNAs appear to be reduced in thyroid cancer, such as the let-7 family, but other miRNAs, such as the miR-200 and miR-30 families, are exclusively downregulated in UTC, indicating that its loss may play a role in the acquisition of more aggressive tumour characteristics (i.e., enhanced cell invasion and migration or dedifferentiation) $(66,67)$. On the other hand, miRNAs such as miR-146, miR-221, miR-222, and miR-17-92 are upregulated in UTC and in well-differentiated thyroid cancer, indicating that reinforced expression of these miRNAs appears to play a role in the maintenance of the oncogenic process (66).

The low-density lipoprotein receptor-related protein gene (LRP1B) originally isolated on the basis of homozygous deletions detected in human lung cancer cell lines (68) is among the top 10 most significantly deleted genes across 3312 human cancer specimens (69). LRP1B localizes at $2 \mathrm{q} 21$, a susceptibility locus for familial non-medullary thyroid cancer and encodes for a member of the endocytic low-density lipoprotein receptor superfamily (68). Our group reported that the LRP1B expression level in UTCs was significantly lower than in differentiated thyroid cancers, and that such reduced expression was due to frameshift mutation and genomic loss of $L R P 1 B$ gene (68). Moreover, 
UTC showed frequent methylation of the promoter region of the gene leading the loss of the expression of LRP1B in more than $80 \%$ of UTCs (68).

Among the proteins whose expression is altered in UTC, some appear as promising novel therapeutic targets namely Aurora kinases and transferrin receptor. In UTC, Aurora kinases are often found overexpressed (70). Aurora kinases are serine/threonine kinases that play an essential role in cell division. Their aberrant expression and/or function induce severe mitotic abnormalities resulting in either cell death or aneuploidy. Baldini et al. (71) reported the in vitro efficacy of Aurora kinase inhibitors (MLN8237 inhibitor for Aurora-A and AZD1152 inhibitor for Aurora-B) in restraining cell growth and survival of four human UTC cell lines (CAL-62, BHT-101, 8305C, 8505C). Baldini showed furthermore that Aurora A inhibition appears to be more effective than that of Aurora B in UTC cell lines (71). These data indicate that inhibitors for overexpressed proteins, such as Aurora kinases, alone or in combination with other drugs, including microtubule inhibitors, display an anticancer effect in preclinical models of UTCs suggesting that this approach may be used as an alternative therapeutic strategy for patients with UTC $(72,73)$.

The TfR1/CD71 is a cell membrane glycoprotein involved in iron homeostasis and cell growth. Parenti et al. (74) reported immunohistochemical data demonstrating the overexpression of TfR1/CD71 in UTC and discuss the possibility of targeting TfR1/CD71 by monoclonal or recombinant antibodies or transferrin-gallium-TfR1/ CD71 molecular complexes or even small interfering RNAs (siRNAs) (74).

Finally, aberrant methylation of gene promoter regions and histone modifications can alter the function of tumour suppressor genes and thus contribute to activation of signalling pathways, such as PI3K-AKT and MAPK cascades. Changes in the epigenetic regulation of oncogenic steps might also lead to downregulation of thyroid-specific genes during tumour progression and dedifferentiation (75).

\section{SMALL CELL THYROID CARCINOMAS}

In thyroid, the smallcell phenotype has been observed mainly in poorly differentiated carcinoma and lymphoma (76). Other primary tumours that may exhibit small cell features include medullary thyroid carcinoma, undifferentiated carcinoma, squamous cell carcinoma, CASTLE, primary extra-skeletal Ewing family tumours (PEEFTs) (76-79) as well as other rare flowers such as neuroblastoma (80) and basaloid neoplasm with solid cell nest features (81). Until now, the rare reports of primary neuroendocrine and nonneuroendocrine small cell carcinomas of the thyroid (82, 83) have not provided enough evidence to support the recognition of a primary small cell carcinoma of the thyroid as an entity.

In 2011, our group reported the first case of carcinoma of the thyroid with Ewing family tumour elements (CEFTE) (9). CEFTE is a unique small cell epithelial tumour that showed neither $\mathrm{C}$ cell nor follicular cell differentiation. It occurs in young patients and presents as large lobulated thyroid nodules. Histologically, CEFTE are unencapsulated, predominantly expansive neoplasms, displaying vascular invasion and growing in a nested pattern consisting of well-defined, variable sized insulae with central necrosis, as well as trabeculae and solid areas (Figure $3 \mathrm{~A}, \mathrm{~B}$ ). The cells are small, uniform, with regular and fairly round nuclei disclosing fine chromatin and variable nucleoli. The
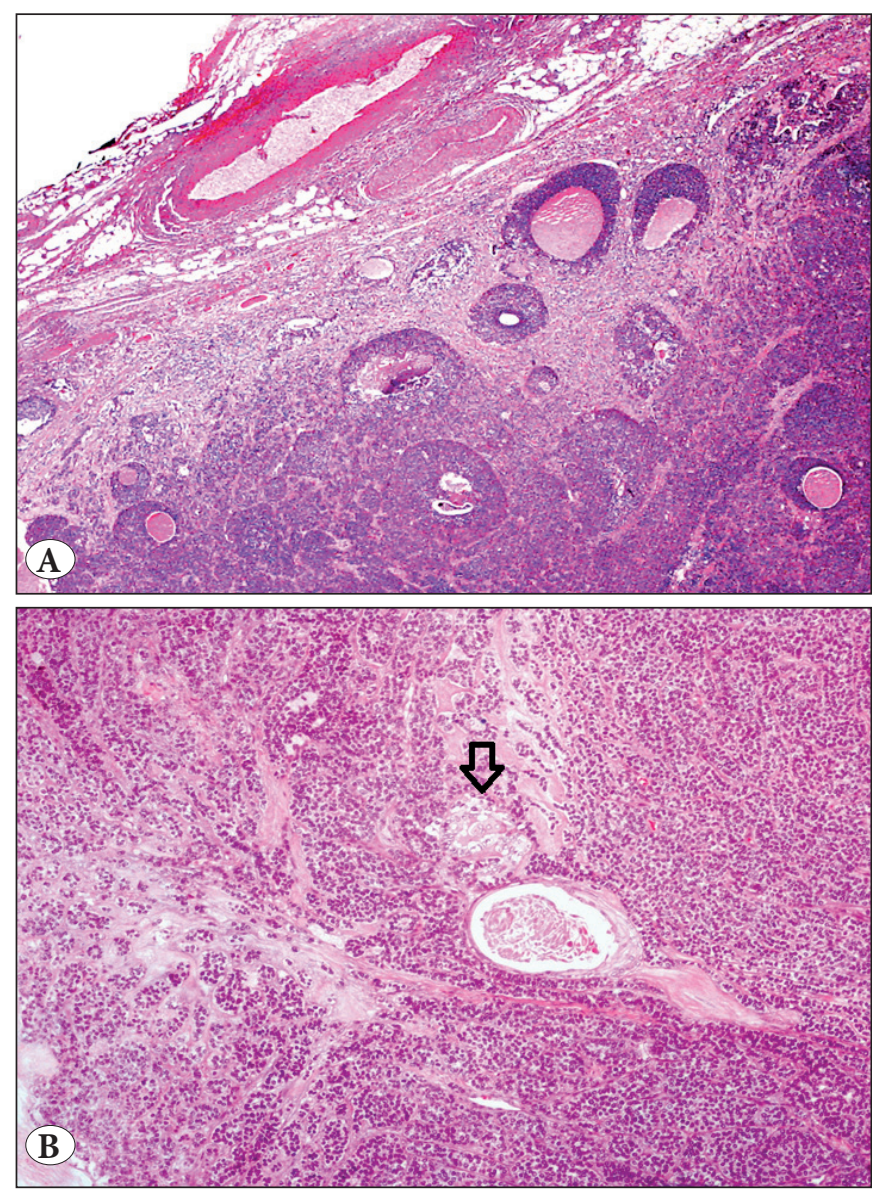

Figure 3: Histological aspect of carcinoma of the thyroid with Ewing family tumour elements (CEFTE): A) Nested pattern area with foci of necrosis (H\&E, 20x), B) The majority of the neoplastic cells are small, there are foci of squamous differentiation and some follicles composed by cells with papillary thyroid carcinoma-type nuclei (arrow) (H\&E, 100x). 
cytoplasm is scant with ill-defined boundaries. Additionally, epidermoid-like areas and co-existing follicular foci with papillary-like nuclear features may be observed (9). Mitotic activity is variable.

The neoplastic cells of CEFTE diffusely express cytokeratins, p63, E-cadherin and CD99 in the absence of vimentin expression (9-11). In Table 3 we summarized the immunohistochemical features of CEFTE. CEFTE should be distinguished from basaloid tumor with solid cell nests features that is a PTC related tumor composed by small cells that express p63, cytokeratin 5 and galectin 3 in the absence of CD5 and CD99 expression (81).

CEFTE discloses the EWSR1-FLI1 rearrangement typical of PEEFTs (9-11) (Figure 4A,B). We do not know if CEFTE should be considered as a type of PEEFT with extensive carcinomatous differentiation, or true small cell nonneuroendocrine carcinoma exhibiting the EWSR1-FLI1 rearrangement. As in other locations, the diagnosis of thyroid PEEFT relies on the detection of the typical EWSR1FLI1 rearrangement (84). The EWSR1 rearrangements with other partners have been reported in other non-PEEFT tumours $(85,86)$.

It is worthwhile stressing the apparent good prognosis of these tumours, despite their poorly differentiated appearance, vascular invasiveness and necrotic foci.

The etiopathogenesis of such small cell carcinomas of the thyroid remains unknown: do they derive from "dedifferentiated" PTC cells that have acquired the EWSR1FLI1 rearrangement and entirely lost thyroid differentiation

Table III: Immunohistochemical features of carcinoma of the thyroid with Ewing family tumour elements (CEFTE)

\begin{tabular}{|l|l|}
\hline Antibody & Expression \\
\hline Pan-cytokeratins & Present \\
\hline Cytokeratin 5 & Absent \\
\hline Cytokeratin19 & Present \\
\hline Vimentin & Absent \\
\hline TTF1 & Absent \\
\hline Thyroglobulin & Absent \\
\hline Calcitonin & Absent \\
\hline p63 & Present \\
\hline Chromogranin & Variable \\
\hline Synaptophysin & Variable \\
\hline CD99 & Present \\
\hline Galectin3 & Absent \\
\hline Ki67 labeling index & Variable \\
\hline
\end{tabular}
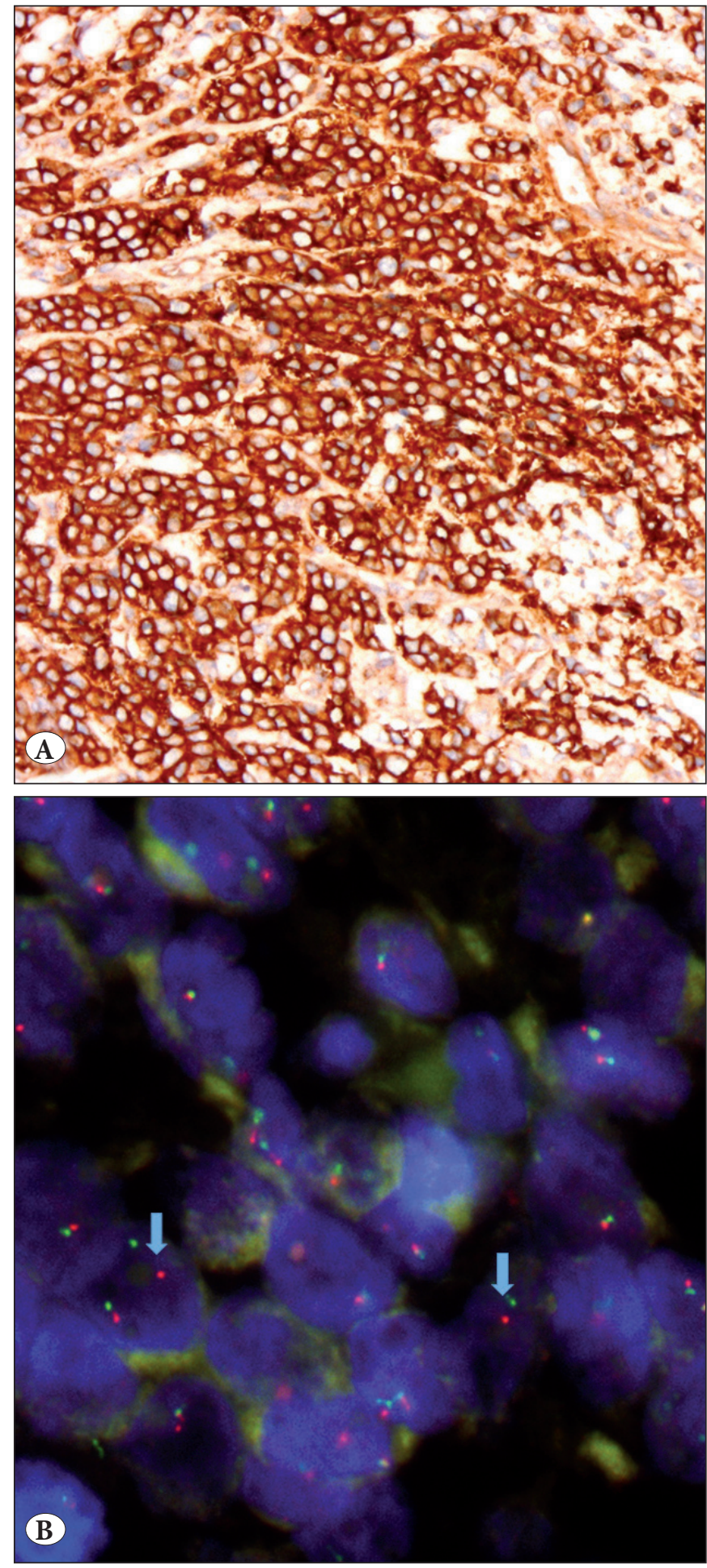

Figure 4: CD99 expression and EWSR1/FLI1 rearrangement in a case of carcinoma of the thyroid with Ewing family tumour elements (CEFTE): A) CD99 diffuse and membrane expression in the small cells (200x), B) EWSR1/FLI1 rearrangement detected by FISH dual color probe in the same case (break apart signs arrow). 
(negativity for TTF-1 and thyroglobulin), or do they originate from thymic/branchial pouch remnants such as the main cells of solid cell nests? (10).

\section{FOUNDING SOURCE}

This study was supported by a $\mathrm{CNPq} \mathrm{PhD}$ Scholarship ("National Counsel of Technological and Scientific Development", Brazil), Science Without Borders, Process n\# 237322/2012-9 for L.F. Further funding was obtained from the project "Microenvironment, metabolism and cancer" that was partially supported by Programa Operacional Regional do Norte (ON.2 - O Novo Norte) under the Quadro de Referência Estratégico Nacional (QREN) and the Fundo Europeu de Desenvolvimento Regional (FEDER). This work is funded by FEDER funds through the Operational Programme for Competitiveness Factors - COMPETE and National Funds through the FCT, under the projects "PEst-C/SAU/LA0003/2013"

\section{CONFLICT OF INTEREST}

Authors declared that they have no conflict of interest.

\section{REFERENCES}

1. DeLellis RA LR HP, Eng C Tumours of endocrine Organs - WHO classification of tumours. 3rd ed. 2004.

2. C. Hedinger EDWLHS. Histological typing of thyroid tumours. 2nd ed. Berlin; 1988.

3. Maximo V, Lima J, Prazeres H, Soares P, Sobrinho-Simoes M. The biology and the genetics of Hurthle cell tumors of the thyroid. Endocr Relat Cancer. 2012;19:R131-47.

4. Nikiforov YE, Nikiforova MN. Molecular genetics and diagnosis of thyroid cancer. Nat Rev Endocrinol. 2011;7:569-80.

5. Garcia-Rostan G, Tallini G, Salvatore G. Anaplastic thyroid carcinoma: Molecular tools for diagnosis and therapy. Int J Endocrinol. 2015;2015:341725.

6. Garcia-Rostan G, Sobrinho-Simoes M. Poorly differentiated thyroid carcinoma: An evolving entity. Diagn. Histopathol. 2011; 17: 114-23.

7. Soares P, Lima J, Preto A, Castro P, Vinagre J, Celestino R, Couto JP, Prazeres H, Eloy C, Máximo V, Sobrinho-Simões M. Genetic alterations in poorly differentiated and undifferentiated thyroid carcinomas. Curr Genomics. 2011;12:609-17.

8. Rosai J DRA CM, Frable WJ, Tallini G. Tumors of the thyroid \& parathyroid glands. 4th ed; 2015.

9. Cruz J, Eloy C, Aragues JM, Vinagre J, Sobrinho-Simoes M. Small-cell (basaloid) thyroid carcinoma: A neoplasm with a solid cell nest histogenesis? Int J Surg Pathol. 2011;19:620-6.

10. Eloy C, Cameselle-Teijeiro J, Vieira J, Teixeira MR, Cruz J, Sobrinho-Simoes M. Carcinoma of the thyroid with Ewing/ PNET family tumor elements: A tumor of unknown histogenesis. Int J Surg Pathol. 2014;22:579-81.
11. Eloy C, Oliveira M, Vieira J, Teixeira MR, Cruz J, SobrinhoSimoes M. Carcinoma of the thyroid with ewing family tumor elements and favorable prognosis: Report of a second case. Int J Surg Pathol. 2014;22:260-5.

12. Eloy C, Cameselle-Teijeiro JM, Rousseau E, Sobrinho-Simoes M. Small cell tumors of the thyroid gland: A review. Int J Surg Pathol. 2014;22:197-201.

13. Volante M, Collini P, Nikiforov YE, Sakamoto A, Kakudo K, Katoh R, Lloyd RV, LiVolsi VA, Papotti M, Sobrinho-Simoes M, Bussolati G, Rosai J. Poorly differentiated thyroid carcinoma: The Turin proposal for the use of uniform diagnostic criteria and an algorithmic diagnostic approach. Am J Surg Pathol. 2007;31:125664.

14. Sobrinho-Simoes M, Sambade C, Fonseca E, Soares P. Poorly differentiated carcinomas of the thyroid gland: A review of the clinicopathologic features of a series of 28 cases of a heterogeneous, clinically aggressive group of thyroid tumors. Int J Surg Pathol. 2002;10:123-31.

15. Sobrinho-Simoes M, Eloy C, Magalhaes J, Lobo C, Amaro T. Follicular thyroid carcinoma. Mod Pathol. 2011;24 Suppl 2:S10-8.

16. Nakazawa T, Celestino R, Machado JC, Cameselle-Teijeiro JM, Vinagre J, Eloy C, Benserai F, Lameche S, Soares P, SobrinhoSimões M. Cribriform-morular variant of papillary thyroid carcinoma displaying poorly differentiated features. Int J Surg Pathol. 2013;21:379-89.

17. Bongiovanni M, Mazzucchelli L, Giovanella L, Frattini M, Pusztaszeri M. Well-differentiated follicular patterned tumors of the thyroid with high-grade features can metastasize in the absence of capsular or vascular invasion: Report of a case. Int J Surg Pathol. 2014;22:749-56.

18. Hiltzik D, Carlson DL, Tuttle RM, Chuai S, Ishill N, Shaha A, Shah JP, Singh B, Ghossein RA. Poorly differentiated thyroid carcinomas defined on the basis of mitosis and necrosis: A clinicopathologic study of 58 patients. Cancer. 2006;106:1286-95.

19. Sobrinho-Simoes M, Máximo V, Rocha AS, Trovisco V, Castro P, Preto A, Lima J, Soares P. Intragenic mutations in thyroid cancer. Endocrinol Metab Clin North Am. 2008;37:333-62, viii.

20. Volante M, Rapa I, Gandhi M, Bussolati G, Giachino D, Papotti $\mathrm{M}$, Nikiforov YE. RAS mutations are the predominant molecular alteration in poorly differentiated thyroid carcinomas and bear prognostic impact. J Clin Endocrinol Metab. 2009;94:4735-41.

21. Wang Y, Hou P, Yu H, Wang W, Ji M, Zhao S, Yan S, Sun X, Liu D, Shi B, Zhu G, Condouris S, Xing M. High prevalence and mutual exclusivity of genetic alterations in the phosphatidylinositol-3kinase/akt pathway in thyroid tumors. J Clin Endocrinol Metab. 2007;92:2387-90.

22. Hou P, Liu D, Shan Y, Hu S, Studeman K, Condouris S, Wang Y, Trink A, El-Naggar AK, Tallini G, Vasko V, Xing M. Genetic alterations and their relationship in the phosphatidylinositol 3-kinase/Akt pathway in thyroid cancer. Clin Cancer Res. 2007;13:1161-70.

23. Liu Z, Hou P, Ji M, Guan H, Studeman K, Jensen K, Vasko V, El-Naggar AK, Xing M. Highly prevalent genetic alterations in receptor tyrosine kinases and phosphatidylinositol 3-kinase/akt and mitogen-activated protein kinase pathways in anaplastic and follicular thyroid cancers. J Clin Endocrinol Metab. 2008;93:310616. 
24. Santarpia L, El-Naggar AK, Cote GJ, Myers JN, Sherman SI Phosphatidylinositol 3-kinase/akt and ras/raf-mitogen-activated protein kinase pathway mutations in anaplastic thyroid cancer. J Clin Endocrinol Metab. 2008;93:278-84.

25. Nikiforova MN, Kimura ET, Gandhi M, Biddinger PW, Knauf JA, Basolo F, Zhu Z, Giannini R, Salvatore G, Fusco A, Santoro M, Fagin JA, Nikiforov YE. BRAF mutations in thyroid tumors are restricted to papillary carcinomas and anaplastic or poorly differentiated carcinomas arising from papillary carcinomas. J Clin Endocrinol Metab. 2003;88:5399-404.

26. Begum S, Rosenbaum E, Henrique R, Cohen Y, Sidransky D, Westra WH. BRAF mutations in anaplastic thyroid carcinoma: Implications for tumor origin, diagnosis and treatment. Mod Pathol. 2004;17:1359-63.

27. Ricarte-Filho JC, Ryder M, Chitale DA, Rivera M, Heguy A, Ladanyi M, Janakiraman M, Solit D, Knauf JA, Tuttle RM, Ghossein RA, Fagin JA. Mutational profile of advanced primary and metastatic radioactive iodine-refractory thyroid cancers reveals distinct pathogenetic roles for BRAF, PIK3CA, and AKT1. Cancer Res. 2009;69:4885-93.

28. Garcia-Rostan G, Tallini G, Herrero A, D’Aquila TG, Carcangiu ML, Rimm DL. Frequent mutation and nuclear localization of beta-catenin in anaplastic thyroid carcinoma. Cancer Res. 1999;59:1811-5

29. Garcia-Rostan G, Camp RL, Herrero A, Carcangiu ML, Rimm DL, Tallini G. Beta-catenin dysregulation in thyroid neoplasms: Down-regulation, aberrant nuclear expression, and CTNNB1 exon 3 mutations are markers for aggressive tumor phenotypes and poor prognosis. Am J Pathol. 2001;158:987-96.

30. Rocha AS, Soares P, Fonseca E, Cameselle-Teijeiro J, Oliveira MC, Sobrinho-Simoes M. E-cadherin loss rather than beta-catenin alterations is a common feature of poorly differentiated thyroid carcinomas. Histopathology. 2003;42:580-7.

31. Pita JM, Figueiredo IF, Moura MM, Leite V, Cavaco BM. Cell cycle deregulation and TP53 and RAS mutations are major events in poorly differentiated and undifferentiated thyroid carcinomas. J Clin Endocrinol Metab. 2014;99:E497-507.

32. Garcia-Rostan G, Costa AM, Pereira-Castro I, Salvatore G, Hernandez R, Hermsem MJ, Herrero A, Fusco A, CameselleTeijeiro J, Santoro M. Mutation of the PIK3CA gene in anaplastic thyroid cancer. Cancer Res. 2005;65:10199-207.

33. Melo M, da Rocha AG, Vinagre J, Batista R, Peixoto J, Tavares C, Celestino R, Almeida A, Salgado C, Eloy C, Castro P, Prazeres H, Lima J, Amaro T, Lobo C, Martins MJ, Moura M, Cavaco B, Leite V, Cameselle-Teijeiro JM, Carrilho F, Carvalheiro M, Máximo V, Sobrinho-Simões M, Soares P. TERT promoter mutations are a major indicator of poor outcome in differentiated thyroid carcinomas. J Clin Endocrinol Metab. 2014;99:E754-65.

34. Vinagre J, Pinto V, Celestino R, Reis M, Pópulo H, Boaventura P, Melo M, Catarino T, Lima J, Lopes JM, Máximo V, SobrinhoSimões M, Soares P. Telomerase promoter mutations in cancer: An emerging molecular biomarker? Virchows Arch. 2014;465:11933.

35. Liu X, Wu G, Shan Y, Hartmann C, von Deimling A, Xing M. Highly prevalent TERT promoter mutations in bladder cancer and glioblastoma. Cell Cycle. 2013;12:1637-8.
36. Vinagre J, Almeida A, Pópulo H, Batista R, Lyra J, Pinto V, Coelho R, Celestino R, Prazeres H, Lima L, Melo M, da Rocha AG, Preto A, Castro P, Castro L, Pardal F, Lopes JM, Santos LL, Reis RM, Cameselle-Teijeiro J, Sobrinho-Simões M, Lima J, Máximo V, Soares P. Frequency of TERT promoter mutations in human cancers. Nat Commun. 2013;4:2185.

37. Landa I, Ganly I, Chan TA, Mitsutake N, Matsuse M, Ibrahimpasic T, Ghossein RA, Fagin JA. Frequent somatic TERT promoter mutations in thyroid cancer: Higher prevalence in advanced forms of the disease. J Clin Endocrinol Metab. 2013;98:E1562-6.

38. Liu X, Bishop J, Shan Y, Pai S, Liu D, Murugan AK, Sun H, ElNaggar AK, Xing M. Highly prevalent TERT promoter mutations in aggressive thyroid cancers. Endocr Relat Cancer. 2013;20:60310.

39. Nikiforova MN, Tseng GC, Steward D, Diorio D, Nikiforov YE. MicroRNA expression profiling of thyroid tumors: Biological significance and diagnostic utility. J Clin Endocrinol Metab. 2008;93:1600-8

40. Somerman MJ, Berry JE, Khalkhali-Ellis Z, Osdoby P, Simpson RU. Enhanced expression of alpha $\mathrm{v}$ integrin subunit and osteopontin during differentiation of HL-60 cells along the monocytic pathway. Exp Cell Res. 1995;216:335-41.

41. Kelly LM, Barila G, Liu P, Evdokimova VN, Trivedi S, Panebianco F, Gandhi M, Carty SE, Hodak SP, Luo J, Dacic S, Yu YP, Nikiforova MN, Ferris RL, Altschuler DL, Nikiforov YE. Identification of the transforming STRN-ALK fusion as a potential therapeutic target in the aggressive forms of thyroid cancer. Proc Natl Acad Sci U S A. $2014 ; 111: 4233-8$

42. Giordano TJ, Kuick R, Thomas DG, Misek DE, Vinco M, Sanders D, Zhu Z, Ciampi R, Roh M, Shedden K, Gauger P, Doherty G, Thompson NW, Hanash S, Koenig RJ, Nikiforov YE. Molecular classification of papillary thyroid carcinoma: Distinct BRAF, RAS, and RET/PTC mutation-specific gene expression profiles discovered by DNA microarray analysis. Oncogene. 2005;24:6646-56.

43. Chevillard S, Ugolin N, Vielh P, Ory K, Levalois C, Elliott D, Clayman GL, El-Naggar AK. Gene expression profiling of differentiated thyroid neoplasms: Diagnostic and clinical implications. Clin Cancer Res. 2004;10:6586-97.

44. Huang Y, Prasad M, Lemon WJ, Hampel H, Wright FA, Kornacker K, LiVolsi V, Frankel W, Kloos RT, Eng C, Pellegata NS, de la Chapelle A. Gene expression in papillary thyroid carcinoma reveals highly consistent profiles. Proc Natl Acad Sci U S A. 2001;98:15044-9.

45. Lubitz CC, Fahey TJ, 3rd. The differentiation of benign and malignant thyroid nodules. Adv Surg. 2005;39:355-77.

46. Prasad NB, Somervell H, Tufano RP, Dackiw AP, Marohn MR, Califano JA, Wang Y, Westra WH, Clark DP, Umbricht CB, Libutti SK, Zeiger MA. Identification of genes differentially expressed in benign versus malignant thyroid tumors. Clin Cancer Res. 2008;14:3327-37.

47. Nikiforov YE. Genetic alterations involved in the transition from well-differentiated to poorly differentiated and anaplastic thyroid carcinomas. Endocr Pathol. 2004;15:319-27.

48. Papp S, Asa SL. When thyroid carcinoma goes bad: A morphological and molecular analysis. Head Neck Pathol. 2015;9:16-23. 
49. Arends JW. Molecular interactions in the Vogelstein model of colorectal carcinoma. J Pathol. 2000;190:412-6.

50. Donghi R, Longoni A, Pilotti S, Michieli P, Della Porta G, Pierotti MA. Gene p53 mutations are restricted to poorly differentiated and undifferentiated carcinomas of the thyroid gland. J Clin Invest. 1993;91:1753-60.

51. Nakamura T, Yana I, Kobayashi T, Shin E, Karakawa K, Fujita S, Miya A, Mori T, Nishisho I, Takai S. p53 gene mutations associated with anaplastic transformation of human thyroid carcinomas. Jpn J Cancer Res. 1992;83:1293-8.

52. Takeuchi Y, Daa T, Kashima K, Yokoyama S, Nakayama I, Noguchi S. Mutations of p53 in thyroid carcinoma with an insular component. Thyroid. 1999;9:377-81.

53. Pilotti S, Collini P, Del Bo R, Cattoretti G, Pierotti MA, Rilke F. A novel panel of antibodies that segregates immunocytochemically poorly differentiated carcinoma from undifferentiated carcinoma of the thyroid gland. Am J Surg Pathol. 1994;18:1054-64.

54. Asakawa H, Kobayashi T. Multistep carcinogenesis in anaplastic thyroid carcinoma: A case report. Pathology. 2002;34:94-7.

55. Ragazzi M, Ciarrocchi A, Sancisi V, Gandolfi G, Bisagni A, Piana S. Update on anaplastic thyroid carcinoma: Morphological, molecular, and genetic features of the most aggressive thyroid cancer. Int J Endocrinol. 2014;2014:790834.

56. Shi X, Liu R, Qu S, Zhu G, Bishop J, Liu X, Sun H, Shan Z, Wang E, Luo Y, Yang X, Zhao J, Du J, El-Naggar AK, Teng W, Xing M. Association of TERT promoter mutation 1,295,228 C $>$ T with BRAF V600E mutation, older patient age, and distant metastasis in anaplastic thyroid cancer. J Clin Endocrinol Metab. 2015;100:E632-7.

57. Hannallah J, Rose J, Guerrero MA. Comprehensive literature review: Recent advances in diagnosing and managing patients with poorly differentiated thyroid carcinoma. Int J Endocrinol. 2013;2013:317487.

58. Asioli S, Erickson LA, Righi A, Jin L, Volante M, Jenkins S, Papotti M, Bussolati G, Lloyd RV. Poorly differentiated carcinoma of the thyroid: Validation of the Turin proposal and analysis of IMP3 expression. Mod Pathol. 2010;23:1269-78.

59. Bond JA, Wyllie FS, Rowson J, Radulescu A, Wynford-Thomas D. In vitro reconstruction of tumour initiation in a human epithelium. Oncogene. 1994;9:281-90.

60. Monaco C, Califano D, Chiappetta G, Mineo A, De Franciscis V, Vecchio G, Santelli G. Mutated human Kirsten ras, driven by a thyroglobulin promoter, induces a growth advantage and partially dedifferentiates rat thyroid epithelial cells in vitro. Int J Cancer. 1995;63:757-60.

61. Portella G, Vitagliano D, Borselli C, Melillo RM, Salvatore D, Rothstein JL, Vecchio G, Fusco A, Santoro M. Human N-ras, TRK-T1, and RET/PTC3 oncogenes, driven by a thyroglobulin promoter, differently affect the expression of differentiation markers and the proliferation of thyroid epithelial cells. Oncol Res. 1999;11:421-7.

62. Cancer Genome Atlas Research N. Integrated genomic characterization of papillary thyroid carcinoma. Cell. 2014;159:676-90.
63. Namba H, Nakashima M, Hayashi T, Hayashida N, Maeda S, Rogounovitch TI, Ohtsuru A, Saenko VA, Kanematsu T, Yamashita S. Clinical implication of hot spot BRAF mutation, V599E, in papillary thyroid cancers. J Clin Endocrinol Metab. 2003;88:4393-7.

64. Dahia PL, Marsh DJ, Zheng Z, Zedenius J, Komminoth P, Frisk T, Wallin G, Parsons R, Longy M, Larsson C, Eng C. Somatic deletions and mutations in the Cowden disease gene, PTEN, in sporadic thyroid tumors. Cancer Res. 1997;57:4710-3.

65. Murugan AK, Xing M. Anaplastic thyroid cancers harbor novel oncogenic mutations of the ALK gene. Cancer Res. 2011;71:440311.

66. Fuziwara CS, Kimura ET. MicroRNA deregulation in anaplastic thyroid cancer biology. Int J Endocrinol. 2014;2014:743450.

67. Visone R, Pallante P, Vecchione A, Cirombella R, Ferracin M, Ferraro A, Volinia S, Coluzzi S, Leone V, Borbone E, Liu CG, Petrocca F, Troncone G, Calin GA, Scarpa A, Colato C, Tallini G, Santoro M, Croce CM, Fusco A. Specific microRNAs are downregulated in human thyroid anaplastic carcinomas. Oncogene. 2007;26:7590-5.

68. Prazeres H, Salgado C, Duarte C, Soares P. LRP1B (low density lipoprotein receptor-related protein 1B). Atlas Genet Cytogenet Oncol Haematol. 2014:93-101.

69. Beroukhim R, Mermel CH, Porter D, Wei G, Raychaudhuri S, Donovan J, Barretina J, Boehm JS, Dobson J, Urashima M, Mc Henry KT, Pinchback RM, Ligon AH, Cho YJ, Haery L, Greulich H, Reich M, Winckler W, Lawrence MS, Weir BA, Tanaka KE, Chiang DY, Bass AJ, Loo A, Hoffman C, Prensner J, Liefeld T, Gao Q, Yecies D, Signoretti S, Maher E, Kaye FJ, Sasaki H, Tepper JE, Fletcher JA, Tabernero J, Baselga J, Tsao MS, Demichelis F, Rubin MA, Janne PA, Daly MJ, Nucera C, Levine RL, Ebert BL, Gabriel S, Rustgi AK, Antonescu CR, Ladanyi M, Letai A, Garraway LA, Loda M, Beer DG, True LD, Okamoto A, Pomeroy SL, Singer S, Golub TR, Lander ES, Getz G, Sellers WR, Meyerson M. The landscape of somatic copy-number alteration across human cancers. Nature. 2010;463:899-905.

70. Ulisse S, Delcros JG, Baldini E, Toller M, Curcio F, Giacomelli L, Prigent C, Ambesi-Impiombato FS, D’Armiento M, ArlotBonnemains Y. Expression of Aurora kinases in human thyroid carcinoma cell lines and tissues. Int J Cancer. 2006;119:275-82.

71. Baldini E, Tuccilli C, Prinzi N, Sorrenti S, Antonelli A, Gnessi L, Morrone S, Moretti C, Bononi M, Arlot-Bonnemains Y, D’Armiento M, Ulisse S. Effects of selective inhibitors of Aurora kinases on anaplastic thyroid carcinoma cell lines. Endocr Relat Cancer. 2014;21:797-811.

72. Isham CR, Bossou AR, Negron V, Fisher KE, Kumar R, Marlow L, Lingle WL, Smallridge RC, Sherman EJ, Suman VJ, Copland JA, Bible KC. Pazopanib enhances paclitaxel-induced mitotic catastrophe in anaplastic thyroid cancer. Sci Transl Med. 2013;5:166ra3.

73. Arlot-Bonnemains Y, Baldini E, Martin B, Delcros JG, Toller M, Curcio F, Ambesi-Impiombato FS, D’Armiento M, Ulisse S. Effects of the Aurora kinase inhibitor VX-680 on anaplastic thyroid cancer-derived cell lines. Endocr Relat Cancer. 2008;15:559-68. 
74. Parenti R, Salvatorelli L, Magro G. Anaplastic thyroid carcinoma: Current treatments and potential new therapeutic options with emphasis on TfR1/CD71. Int J Endocrinol. 2014;2014:685396.

75. Russo D, Damante G, Puxeddu E, Durante C, Filetti S. Epigenetics of thyroid cancer and novel therapeutic targets. J Mol Endocrinol. 2011;46:R73-81.

76. Schmid KW, Kroll M, Hofstadter F, Ladurner D. Small cell carcinoma of the thyroid. A reclassification of cases originally diagnosed as small cell carcinomas of the thyroid. Pathol Res Pract. 1986;181:540-3.

77. Rosai J, Saxen EA, Woolner L. Undifferentiated and poorly differentiated carcinoma. Semin Diagn Pathol. 1985;2:123-36.

78. Meissner WA, Warren S. Tumours of the thyroid gland. 2nd ed. Washington, DC: Armed Forces Institute of Pathology; 1969.

79. Chan JM, Bilodeau E, Celin S, Nikiforov Y, Johnson JT. Ewing sarcoma of the thyroid: Report of 2 cases and review of the literature. Head Neck. 2013;35:E346-50.

80. Kumar M, Gupta P, Chaubey A. The thyroid: An extremely rare primary site of neuroblastoma. Hum Pathol. 2006;37:1357-60.

81. Eloy C, Vinagre J, Cameselle-Teijeiro J, Paiva ME, Soares P, Sobrinho-Simoes M. Tumor-in-tumor of the thyroid with basaloid differentiation: A lesion with a solid cell nest neoplastic component? Int J Surg Pathol;19:276-80.
82. Beach DF, Klump WJ, Haddad G, Reid LM, Schwarting R, Hageboutros A. Extrapulmonary small cell: A novel case of small cell carcinoma of the thyroid gland. Med Oncol. 2012;29:1405-8.

83. Luna MA, Mackay B, Hill CS, Hussey DH, Hickey RC. The quarterly case: Malignant small cell tumor of the thyroid. Ultrastruct Pathol. 1980;1:265-70.

84. Maldi E, Monga G, Rossi D, Tosoni A, Mezzapelle R, Boldorini R. Extra-osseous Ewing sarcoma of the thyroid gland mimicking lymphoma recurrence: A case report. Pathol Res Pract. 2012;208:356-9.

85. Malone VS, Dobin SM, Jones KA, Donner LR. CD99-positive large cell neuroendocrine carcinoma with rearranged EWSR1 gene in an infant: A case of prognostically favorable tumor. Virchows Arch. 2010;457:389-95.

86. Jin R, Craddock KJ, Irish JC, Perez-Ordonez B, Weinreb I. Recurrent hyalinizing clear cell carcinoma of the base of tongue with high-grade transformation and EWSR1 gene rearrangement by FISH. Head Neck Pathol. 2012;6:389-94. 